\title{
Embryonic development of Aedes aegypti (Diptera: Culicidae): influence of different constant temperatures
}

\author{
Luana Cristina Farnesi, Ademir Jesus Martins, Denise Valle, Gustavo Lazzaro Rezende/ ${ }^{+}$ \\ Laboratório de Fisiologia e Controle de Artrópodes Vetores, Instituto Oswaldo Cruz- Fiocruz, Rio de Janeiro, RJ, Brasil, \\ Laboratório de Entomologia, Instituto de Biologia do Exército, Rio de Janeiro, RJ, Brasil
}

\begin{abstract}
Despite its vector importance little attention is given to Aedes aegypti embryonic development. In this study, temperature influence on time course of Ae. aegypti larvae hatching and egg viability were evaluated. The dormancy state at the end of embryogenesis could be interrupted with a proper stimulus. Temperatures tested ranged between $12-36^{\circ} \mathrm{C}$; the maximum temperature limit is $35^{\circ} \mathrm{C}$ and the minimum one is below $12^{\circ} \mathrm{C}$. Egg viability between $16-311^{\circ} \mathrm{C}$ was above $80 \%$. The definition of physiological embryonic parameters at this temperature range corroborates Ae. aegypti presence on tropical and subtropical world regions.
\end{abstract}

Keywords: Aedes aegypti - embryogenesis - temperature influence

Dengue and yellow fever are considered two of the most important viral diseases transmitted by arthropods (Gould \& Solomon 2008). The mosquito Aedes aegypti, vector of urban yellow fever and also the main dengue vector, is widely distributed worldwide, being usually found between latitudes $35^{\circ} \mathrm{N}$ and $35^{\circ} \mathrm{S}$ (OPAS, 1995). Ae. aegypti embryos tend to enter dormancy at the end of embryogenesis, being able to keep its viability inside the egg for six months or more, according to the environmental relative humidity (Christophers 1960, Kliewer 1961, Clements 1992). When the surroundings become favorable to larval development, e.g. flooding of larvae habitat, dormancy is interrupted and the larva hatches (Christophers 1960, Clements 1992). Little attention has been given to the influence of temperature on Ae. aegypti embryonic development, when compared to other mosquito species (Rosay 1959, Christophers 1960, Trpiš et al. 1973, Clements 1992, Gillooly \& Dodson 2000). The precise time Ae. aegypti takes to complete its embryogenesis at distinct temperatures is not known (Christophers 1960, Consoli \& Lourenço-de-Oliveira 1994). In the present work the influence of distinct constant temperatures on Ae. aegypti embryogenesis, egg viability and the time course of larval hatching were analyzed.

To induce Ae. aegypti larval eclosion from eggs previously stored in our laboratory for one month, preliminary tests were performed utilizing conditions described as effective stimuli in the literature (Gander 1951, Barbosa \& Peters 1969, Novak \& Shoroyer 1978). In all cases mosquitoes from the Rockefeller strain were used. The conditions used were: (i) dechlorinated water; (ii) deaerated dechlorinated water; (iii) $0.3 \mathrm{mM}$ ascorbic acid in

Financial support: CNPq, FAPERJ, FIOCRUZ

+ Corresponding author: rezendeg@ioc.fiocruz.br

Received 14 October 2008

Accepted 13 January 2009 dechlorinated water; (iv) $0.3 \%(\mathrm{w} / \mathrm{v})$ yeast extract (SIGMA \# Y1625) solution in dechlorinated water (YES); (v) $0.3 \%(\mathrm{w} / \mathrm{v})$ yeast extract solution in deaerated water. All solutions above were freshly made. The best stimulus for Ae. aegypti larval hatching, in our laboratory conditions, is the $0.3 \%(\mathrm{w} / \mathrm{v})$ YES, the rate of egg hatching being $80 \%$ on average (data not shown).

We observed that the embryonic dormancy state of Ae. aegypti is facultative, as expected for a multivoltine species (Forattini 2002), and could be bypassed by adding YES at the end of embryogenesis. Preliminary experiments have been performed in order to time this event, by adding YES at distinct hours after egg laying. Synchronous egg laying was performed during $20 \mathrm{~min}$, as recently described (Rezende et al. 2008). After this period, eggs were kept at the distinct temperatures employed in the experiments. The precise moment of hatching of the first larvae was then observed for each temperature (see Table for the values). For all further experiments, YES was added $2 \mathrm{~h}$ before this moment. In this way, it was possible to monitor Ae. aegypti eclosion immediately after completion of embryonic development. For each experiment at a constant temperature, triplicates from the same egg laying were utilized. These eggs were kept on moist Whatman \# 1 paper until YES was added. From this moment on, larvae hatching was observed every 30 min, until no more hatching occurred. Three experiments were performed for each tested temperature, on different days and with different egg batches, except at $16^{\circ} \mathrm{C}$ and $35^{\circ} \mathrm{C}$ when two experiments were performed.

Relevant parameters of embryogenesis at distinct temperatures are shown on Table. Eclosion rates above $90 \%$ were observed between $22-28^{\circ} \mathrm{C}$. These values dropped to $80 \%$ at $16^{\circ} \mathrm{C}$ and $31^{\circ} \mathrm{C}$ and at $35^{\circ} \mathrm{C}$ the eclosion rate was approximately $50 \%$. No hatching was observed above $36^{\circ} \mathrm{C}$, although viability tests at $26^{\circ} \mathrm{C}$ indicate normal eclosion of eggs from the same egg batches. Therefore, $35^{\circ} \mathrm{C}$ was defined as the maximum temperature supported for embryonic development of Ae. aegyp$t i$. The velocity of the completion of embryonic development is directly proportional to the temperature, except 
TABLE

Temperature parameters during Aedes aegypti embryonic development

\begin{tabular}{|c|c|c|c|c|c|}
\hline \multirow{2}{*}{$\begin{array}{l}\text { Temp } \\
{ }^{\circ} \mathrm{C}\end{array}$} & \multicolumn{3}{|c|}{ Hours after egg laying } & \multirow[b]{2}{*}{$\Delta \mathrm{t}^{* * *}$} & \multirow{2}{*}{$\begin{array}{c}\text { Eclosion } \\
\%\end{array}$} \\
\hline & Completion of embryogenesis* & First L1** & Last L1** & & \\
\hline 16 & $489.3 \pm 0.6$ & 482 & 493.5 & 11.5 & $81.1 \pm 3.2^{a}$ \\
\hline 22 & $98.3 \pm 0.7$ & 95 & 102 & 7.0 & $93.9 \pm 3.1^{b}$ \\
\hline 25 & $77.4 \pm 0.8$ & 74 & 79 & 5.0 & $96.0 \pm 2.0^{b}$ \\
\hline 28 & $61.6 \pm 1.2$ & 59.5 & 66 & 6.5 & $93.3 \pm 3.6^{b}$ \\
\hline 31 & $48.4 \pm 0.5$ & 47.5 & 50.5 & 3.0 & $82.8 \pm 5.3^{a}$ \\
\hline 35 & $50.3 \pm 0.3$ & 49.5 & 51 & 1.5 & $48.5 \pm 9.4^{c}$ \\
\hline 36 & - & $\mathrm{NE}^{\S}$ & - & - & - \\
\hline
\end{tabular}

letters are related to ANOVA. Equal letters indicate absence of significant variation; $\left(\mathrm{n}=600\right.$ eggs for $16^{\circ} \mathrm{C}, \mathrm{n}=360$ eggs for $22^{\circ} \mathrm{C}, 25^{\circ} \mathrm{C}, 28^{\circ} \mathrm{C}$ or $31^{\circ} \mathrm{C}, \mathrm{n}=300$ eggs for $35^{\circ} \mathrm{C}$ ); *: mean eclosion of $50 \%$ of larvae specimens with standard deviation; $* * \mathrm{~L} 1$ : first instar larvae; ${ }^{* * *}$ : hours elapsed between hatching of first and last larva; $\uparrow:$ values are normalized average \pm standard error; $\S$ NE: no eclosion was observed.

at $35^{\circ} \mathrm{C}$, where completion is slower than at $31^{\circ} \mathrm{C}$ (Table, Fig. 1). Our hypothesis is that this delay is due to a greater physiological stress during embryogenesis, caused by the high temperature at which Ae. aegypti embryos were exposed. The same phenomenon is observed during larval development of this species, which takes longer at $33^{\circ} \mathrm{C}$ than at $31^{\circ} \mathrm{C}$ (Gilpin \& McClelland 1979).

After about 960 h (40 days) egg hatching was observed at $12^{\circ} \mathrm{C}$. Clarification of eggs $(n=300)$ kept at $12^{\circ} \mathrm{C}$ for 13 days (approximately $312 \mathrm{~h}$ ), indicated embryos were still in early stages of development (data not shown). Christophers (1960) observed that $7^{\circ} \mathrm{C}$ completely inhibits Ae. aegypti embryogenesis. Therefore, while the minimum temperature supported by this species during embryonic development has not been determined, it can be stated that it falls between $7-12^{\circ} \mathrm{C}$. In any case, the definition of Ae aegypti physiological embryonic parameters for temperatures between $12-35^{\circ} \mathrm{C}$ is in accordance with the distribution of urban yellow fever and dengue in the tropical and subtropical regions of the globe (Guzmán \& Kourí 2002, Barrett \& Higgs 2007).

Using the hatching stimuli methodology with YES, we found $A e$. aegypti embryonic development at $25^{\circ} \mathrm{C}$ is completed at $77.5 \mathrm{~h}$. However, based on morphological parameters, Raminani and Cupp (1978) previously reported Ae. aegypti embryogenesis takes $96 \mathrm{~h}$ at this temperature. With Trpiš clarification solution (Trpiš 1970, Rezende et al. 2008) we analyzed whether there were apparent morphological differences between embryos $77.5 \mathrm{~h}$ and $96 \mathrm{~h}$ old. In both cases embryos displayed the same external morphological characters, i.e., separated head, three fused thoracic segments, eight abdominal segments and respiratory siphon with associated structures (Christophers 1960) (Fig. 2). Additionally, embryos hatched at $77.5 \mathrm{~h}$ were followed up to the end of pupae stage, exhibiting similar viability rate to embryos left to hatch at 96 h. $70.5 \%$ and $73.9 \%$ of embryos hatched at $77.5 \mathrm{~h}$ and $96 \mathrm{~h}$ developed up to the pupa stage, respectively ( $n=120$ eggs for each condition). Development of the hatching spine, the larval structure that assists egg- shell opening in the course of hatching, is accomplished $75 \mathrm{~h}$ after egg laying at $25^{\circ} \mathrm{C}$ (Raminani \& Cupp 1978). This observation led us to hypothesize that presence of a fully developed hatching spine could be an indication that larvae are ready to hatch, which eventually happens when the YES is added.

In warm and humid countries, such as Brazil, dengue is still a serious public health problem, where environmental conditions favor the development and proliferation of its vector (Lourenço-de-Oliveira 2008). There is an influence of temperature on development and reproduction of Ae. aegypti populations in the wild. Field studies correlate a temperature effect over mosquito abundance (Lourenço-de-Oliveira 2008, NA Honório, personal communication) or even with the absence of oviposition activity and immature forms during the winter (Vezzani \& Carbajo 2008).

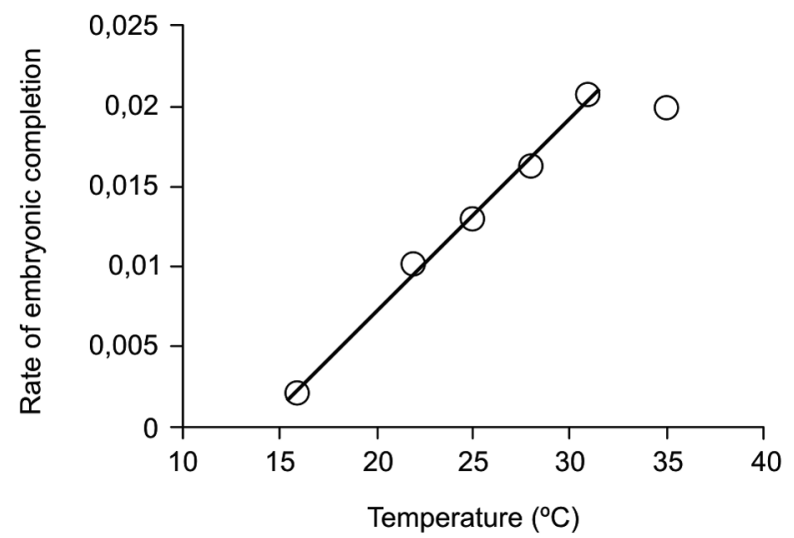

Fig. 1: rate of embryonic development completion of Aedes aegypti as a function of temperature. The rate is calculated as the reciprocal of the time for completion of embryogenesis (Table). In all cases data are shown as average of the experiments for each point. A linear regression $\left(R^{2}=0.9955, p=0.0001\right)$ was performed with values between $16-31^{\circ} \mathrm{C}$. 

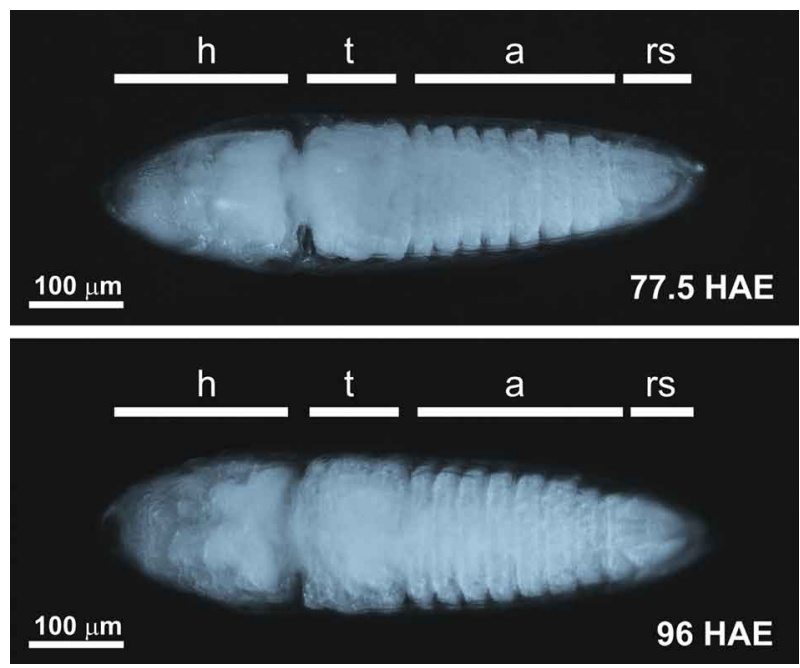

Fig. 2: Morphological pattern of Aedes aegypti embryos at the end of embryogenesis at $25^{\circ} \mathrm{C}$. Upper panel: larva at $77.5 \mathrm{~h}$ after egg laying (HAE); lower panel: larva at 96 HAE. Both larvae have the same external morphological traits. a: eight abdominal segments; h: head; rs: respiratory siphon and associated structures; $\mathrm{t}$ : three fused thoracic segments. Embryos are in a ventral position.

Moreover, knowledge of the effect of temperature on the embryonic development of culicids may serve as a basis for other studies such as the possibility of systematic evaluation of gene expression and physiological changes during embryogenesis (Rezende et al. 2008). The precise identification of embryonic kinetics can also assist the development of new alternatives to the control of disease vectors, based on information obtained from embryological studies.

\section{ACKNOWLEDGEMENTS}

To Jutta Gerlinde Birgitt Linss, for translating the Gander paper, and Rafaela Vieira Bruno and the reviewers, for critical reading and suggestions on the manuscript.

\section{REFERENCES}

Barbosa P, Peters TM 1969. A comparative study of egg hatching techniques for Aedes aegypti. Mosq News 29: 548-551.

Barrett ADT, Higgs S 2007. Yellow fever: a disease that has yet to be conquered. Ann Rev Entomol 52: 209-229.

Christophers SR 1960. Aedes aegypti. The yellow fever mosquito. Its life history, bionomics and structure, Cambridge University Press, London, 738 pp.
Clements AN 1992. The biology of mosquitoes. Development, nutrition and reproduction, Chapman and Hall, London, 509 pp.

Consoli R, Lourenço-de-Oliveira R 1994. Principais mosquitos de importância sanitária no Brasil, Fiocruz, Rio de Janeiro, 228 pp.

Forattini OP 2002. Culicidologia Médica, Vol. 2, Identificação, Biologia, Epidemiologia, Edusp, São Paulo, 860 pp.

Gander R 1951. Experimentelle und Oekologische Untersuchungen über das Schlüpfvermögen der Larven von Aedes aegypti. Rev Suisse Zool 58: 215-278.

Gillooly JF, Dodson SI 2000. The relationship of egg size and incubation temperature to embryonic development time in univoltine and multivoltine aquatic insects. Freshwather Biol 44: 595-604.

Gilpin ME, McClelland GAH 1979. Systems analysis of the yellow fever mosquito Aedes aegypti. Fortschritte Zool 25: 355-388.

Gould EA, Solomon T 2008. Pathogenic flaviviruses. Lancet 371: 500-509.

Guzmán MG, Kourí G 2002. Dengue: and update. Lancet Infect Dis 2: $33-42$.

Kliewer JW 1961. Weight and hatchability of Aedes aegypti eggs. Ann Entomol Soc Am 54: 912-917.

Lourenço-de-Oliveira R 2008. Rio de Janeiro against Aedes aegypti: yellow fever in 1908 and dengue in 2008. Mem Inst Oswaldo Cruz 103: 627-628

Novak RJ, Shoroyer DA 1978. Eggs of Aedes triseriatus and Aedes hendersoni: a method to stimulate optimal hatch. Mosq News 38: 515-521.

OPAS - Organización Panamericana de la Salud 1995. Dengue y dengue hemorrágico en las Américas: guías para su prevención y control, OPAS, Washington, $116 \mathrm{pp}$.

Raminani LN, Cupp EW 1978. Embryology of Aedes aegypti (L.) (Diptera: Culicidae): organogenesis. Int J Insect Morphol \& Embryol 7: 273-296.

Rezende GL, Martins AJ, Gentile C, Farnesi LC, Pelajo-Machado M, Peixoto AA, Valle D 2008. Embryonic desiccation resistance in Aedes aegypti: presumptive role of the chitinized serosal cuticle. BMC Developmental Biology 8: 82 .

Rosay B 1959. Gross external morphology of embryos of Culex tarsalis Coquillett (Diptera:Culicidae). Ann Entomol Soc Am 52: 481-484.

Trpiš M 1970. A new bleaching and decalcifying method for general use in zoology. Can J Zool 48: 892-893.

Trpiš M, Haufe WO, Shemanchuk JAM 1973. Embryonic development of Aedes (O.) sticticus in relation to different constant temperatures. Can Entomol 105: 43-50.

Vezzani D, Carbajo AE 2008. Aedes aegypti, Aedes albopictus and dengue in Argentina: current knowledge and future directions. Mem Inst Oswaldo Cruz 103: 66-74. 